\title{
Penguatan Mutu Baca Tulis Al-Qur'an (BTA) Melalui Metode Al- Masyhuroh Berbasis Life Skill Pengolahan Limbah Ikan pada Komunitas Nelayan Tanjung Mas Semarang
}

\author{
Nur Khoiri, Mustopa, Wirda Udaibah \\ Universitas Islam Negeri Walisongo Semarang \\ Email : nurkhoiri@walisongo.ac.id
}

\begin{abstract}
Assistance to the community is provided in order to provide education using fast, good and correct learning methods. In addition to literacy education of the Qur'an, coastal communities who work as fish seekers on average also need to be equipped with skills (life skill). Through education and training, coastal communities will have two advantages at once, first able to study the Qur'an quickly, rightly and correctly, and both gain knowledge about fish waste processing. Devotion is done also provide life skill education (life skills) such as processing pellets / feed from fish waste. Supply provided is not limited to the training course but also helps in the management of production permits and feasibility of processing the pellet, and find opportunities in marketing the processed products.
\end{abstract}

Abstrak: Pendampingan kepada masyarakat diberikan dalam rangka memberikan pendidikan dengan menggunakan metode belajar yang cepat, baik dan benar. Selain pendidikan baca tulis al-Qur'an, masyarakat pesisir yang rata-rata bekerja sebagai pencari ikan juga perlu dibekali keterampilan (life skill). Melalui pendidikan dan pelatihan, masyarakat pesisir akan memperoleh dua keuntungan sekaligus, pertama dapat mengaji al-Qur'an dengan cepat, baik dan benar, kedua memperoleh pengetahuan tentang pengolahan limbah ikan. Pengabdian yang dilakukan juga memberikan pendidikan keterampilan hidup (life skill) diantaranya adalah pengolahan pelet/pakan dari limbah ikan. Bekal yang diberikan tidak sebatas pada pelatihan saja tetapi juga membantu dalam pengurusan ijin produksi dan kelayakan pengolahan pelet tersebut, serta mencarikan peluang dalam pemasaran hasil olahan tersebut.

Kata Kunci: Baca Tulis Al-Qur'an, Metode al-Masyhuroh, Pengolahan Limbah Ikan. 


\section{PENDAHULUAN}

Daerah Pesisir adalah suatu daerah di sepanjang daerah pantai utara pulau Jawa. Daerah sepanjang pantai utara (pesisiran) pulau Jawa ini dibagi ke dalam dua kategori yaitu Pesisiran Barat dan Pesisiran Timur. Yang pertama, meliputi daerah-daerah: Demak, Kendal, Batang, Pekalongan, Pemalang, Wirodesa, Tegal, dan Brebes. Yang kedua meliputi daerah: Cengkal Sewu, Surabaya, Gresik, Sedayu, Tuban, Lasem, Juwana, Pati, Kudus, dan Jepara (De Graaf, 1949; Schrieke, 1959, dan Ricklefs, 1974. Dikutip dari Hardjowirogo, 1983: 105).

Masyarakat pesisiran menunjukkan beberapa ciri yang berbeda dengan masyarakat lainnya. Beberapa kriteria sikapnya yang cenderung lugas, spontan, tutur kata yang digunakan cenderung menggunakan bahasa ngoko. Keseniannya relatif kasar dalam arti tidak rumit, corak keagamaannya cenderung Islam puritan, dan mobilitasnya cukup tinggi. Kegiatan keagamaan umumnya ramai saat acara nyadran atau sedekah laut. Minat masyarakat dalam kegiatan kegamaan seperti mengaji Al Qur'an dapat dikatakan rendah. Hal ini dapat dipahami karena umumnya mereka berangkat menangkap ikan saat petang/malam dan pulang saat fajar/pagi. Padahal umumnya waktu-waktu tersebut banyak digunakan masyarakat untuk belajar, mengaji dan kegiatan keagamaan lain. Corak berkehidupan sosialnya cenderung egaliter. Mereka lebih menghormati tokoh-tokoh informal seperti kyai dari pada pejabat pemerintah.

Dengan kondisi tersebut kebanyakan diantara mereka yang masih buta baca tulis al-Qur'an, sehingga dengan adanya program pendampingan penuntasan buta baca tulis al-Qur'an dapat dimaksimalkan. Kemudian dampak dari kegiatan tersebut bagi lingkungan masyarakat adalah terwujudnya masyarakat yang dapat membaca dan menulis al-Qur'an atau huruf arab, dan juga menghidupkan kembali majlis-majlis ta'lim atau pertemuan rutin yang bersifat agamis bagi masyarakat guna menambah ilmu keagamaan mereka. Selain pendidikan baca tulis al-Qur'an, masyarakat juga dibekali ketrampilan (life skill) memanfaatkan hasil tangkapan ikan seperti; pengolahan limbah ikan menjadi pakan ikan yang dapat menunjang perekonomian bagi komunitas nelayan. Dengan pendidikan dan pelatihan ini, masyarakat mendapatkan dua keuntungan sekaligus dapat mengaji dengan baik dan benar dan memperoleh pengetahuan tentang pengolahan limbah ikan. Dengan demikian akan terbentuk masyarakt yang religius dan anggapan kaun pesisir adalah kaum marginal di bidang ekonomi dapat diminimalkan.

Masyarakat pesisir selama ini dianggap sebagai masyarakat marginal baik dalam hal pendidikan maupun ekonomi. Isu yang diangkat dalam program pengabdian ini adalah pendidikan dan pelatihan kepada masyarakat. Pendidikan 
dalam hal peningkatan mutu baca tulis Al Qur'an dan Pelatihan berupa pemanfaatan ikan dan limbah ikan menjadi pakan ikan. Adapun Fokus Pengabdian dalam program ini antara lain masyarakat dampingan terbatas pada Komunitas Nelayan "Sido Mulyo" Kelurahan Tanjung Mas Semarang Timur yang terdiri dari 24 orang. Terdiri dari 16 orang jamaah laki-laki dan 8 orang jamaah perempuan.

Pihak-pihak yang terlibat dalam program pengabdian kepada masyarakat ini adalah perangkat desa termasuk petinggi, ketua RW dan ketua RT, tokoh masyarakat dan tokoh agama serta kelompok-kelompok masyarakat yang ada di kelurahan Tanjung Mas Semarang Timur. Serta Pemerintah Kecamatan dan Pemerintah Kabupaten serta Dinas-dinas terkait seperti Dinas Kelautan dan Perikanan Kota Semarang.

Kondisi dampingan yang diharapkan dari kegiatan ini adalah terbebasnya buta baca tulis al-Qur'an berbasis life skill bagi komunitas nelayan "Sido Mulyo" Kelurahan Tanjung Mas Semarang Timur. Target kegiatan penuntasan Buta Baca Tulis al-Qur'an (BTA) ini adalah terbebasnya komunitas nelayan di Kelurahan Tanjung Mas Semarang Timur dari buta baca tulis al Qur'an. Masyarakat atau warga ngaji yang sudah dapat membaca dan menulis huruf arab dan yang dinyatakan lulus dalam evaluasi uji kompetensi baca tulis al-Qur'an diberikan Surat Keterangan Melek Huruf Arab atau yang disebut dengan Syahadah. Warga juga diberi bekal keterampilan (life skill) berupa pakan ikan berbentuk pelet yang dapat dijadikan sebgai peluang usaha selain menagkap ikan. Hal ini dapat menunjang perekonomian keluarga mereka.

\section{ANALISIS SISTUASI/KONDISI DAMPINGAN}

Subyek pendampingan adalah Komunitas Nelayan "Sido Mulyo" Kelurahan Tanjung Mas Semarang Timur yang stratifikasi buta baca tulis alQur'annya sebagai berikut; memiliki kemampuan membaca baru 30\% (7 orang dari 24 orang), menulis 10\% (2 orang dari 24 orang), kemampuan membaca dan menulis $20 \%$ (4 orang dari 24 orang) dan menghafal surat-surat pendek sesuai tajwid dan makhorijul huruf baru 20\% (4 orang dari 24 orang). Untuk Lebih Jelasnya dapat dilihat pada Gambar 1.

Hal ini berarti bahwa penyandang buta baca tulis al-Qur'an pada komunitas Nelayan "Sido Mulyo" di Kelurahan Tanjung Mas Semarang Timur adalah sebagai berikut; belum bisa membaca $70 \%$ (16 orang dari 24 orang), belum bisa menulis $90 \%$ (21 orang dari 24 orang), belum bisa membaca dan menulis $80 \%$ (19 orang dari 24 orang) dan belum bisa menghafal surat-surat 
pendek sesuai dengan tajwid dan makhorijul huruf $80 \%$ (19 orang dari 24 orang).

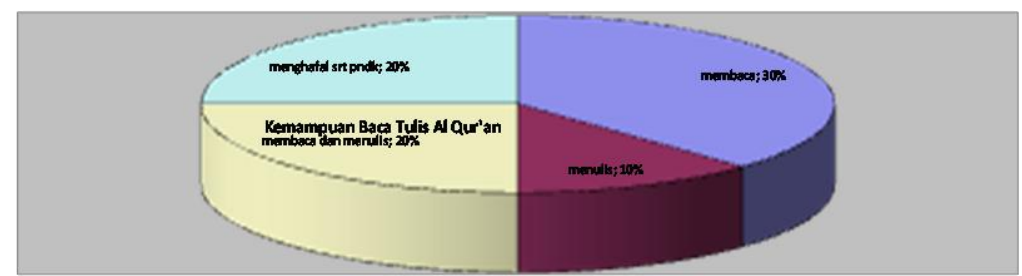

Gambar 1. Grafik yang menunjukkan kemampuan BTA Komunitas Nelayan "Sido Mulyo" Tanjung Mas

Kemudian hasil penelitian tentang kondisi ekonomi komunitas nelayan sebesar 90\% memiliki penghasilan di bawah upah minimum regional (UMR) Kota Semarang yaitu kurang dari Rp 1.950.000, sedangkan 10\% di atas UMR, sebagaimana dalam tabel berikut:

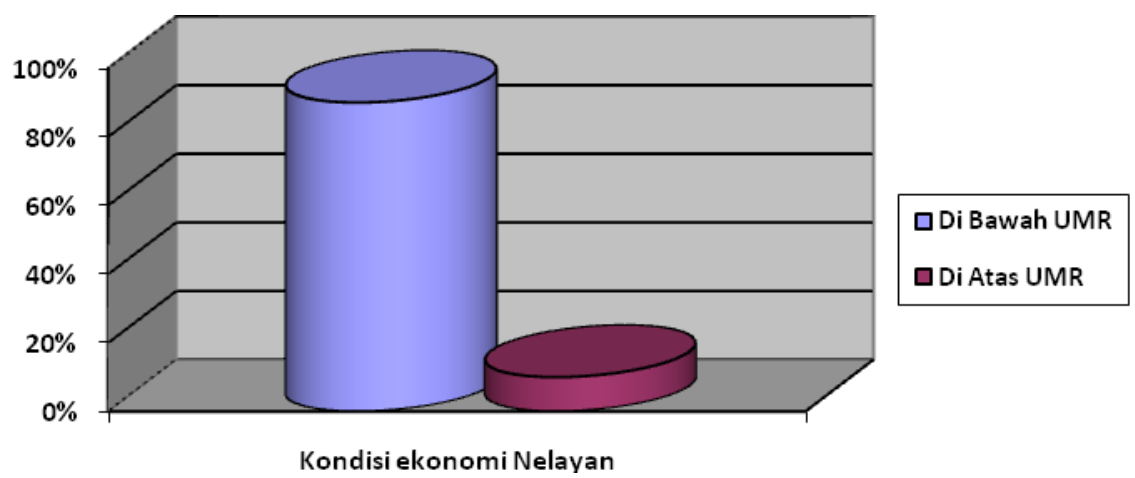

Gambar 2. Grafik tentang Kondisi Ekomoni Komuntas Nelayan"Sido Mulyo" Tanjung Mas

Beberapa faktor yang mempengaruhi kondisi perekonomian masyarakat pesisir atau komunitas nelayan berada di bawah standar rata-rata UMR Kota Semarang, antara lain: a) sumber utama pendapatan hanya dari hasil penangkapan ikan, b) faktor alam atau musim yang menyebabkan waktu-waktu tertentu para nelayan tidak dapat melaut, dan c) tidak memiliki keterampilan lain yang dapat menunjang perekonomian keluarga selain menangkap ikan. 


\section{ISU DAN FOKUS PENGABDIAN}

Masyarakat pesisir selama ini dianggap sebagai masyarakat marginal baik dalam hal pendidikan maupun ekonomi. Isu yang diangkat dalam program pengabdian ini adalah pendidikan dan pelatihan kepada masyarakat. Pendidikan dalam hal peningkatan mutu baca tulis Al Qur'an dan Pelatihan berupa pemanfaatan ikan dan limbah ikan menjadi pakan ikan

Adapun Fokus Pengabdian dalam program ini antara lain masyarakat dampingan terbatas pada Komunitas Nelayan "Sido Mulyo" Kelurahan Tanjung Mas Semarang Timur yang terdiri dari 24 orang. Terdiri dari 16 orang jamaah laki-laki dan 8 orang jamaah perempuan.

Pihak-pihak yang terlibat dalam program pengabdian kepada masyarakat ini adalah perangkat desa termasuk petinggi, ketua RW dan ketua RT, tokoh masyarakat dan tokoh agama serta kelompok-kelompok masyarakat yang ada di kelurahan Tanjung Mas Semarang Timur. Serta Pemerintah Kecamatan dan Pemerintah Kabupaten serta Dinas-dinas terkait seperti Dinas Kelautan dan Perikanan Kota Semarang

Kondisi dampingan yang diharapkan dari kegiatan ini adalah terbebasnya buta baca tulis al-Qur'an berbasis life skill bagi komunitas nelayan "Sido Mulyo" Kelurahan Tanjung Mas Semarang Timur. Target kegiatan penuntasan Buta Baca Tulis Al-Qur'an (BTA) ini adalah terbebasnya komunitas nelayan di Kelurahan Tanjung Mas Semarang Timur dari buta baca tulis al Qur'an. Masyarakat atau warga ngaji yang sudah dapat membaca dan menulis huruf arab dan yang dinyatakan lulus dalam evaluasi uji kompetensi baca tulis al-Qur'an diberikan Surat Keterangan Melek Huruf Arab atau yang disebut dengan Syahadah. Warga juga diberi bekal keterampilan (life skill) berupa pakan ikan berbentuk pelet yang dapat dijadikan sebgai peluang usaha selain menagkap ikan. Hal ini dapat menunjang perekonomian keluarga mereka.

\section{PELATIHAN LIFE SKILL PEMBUATAN PELET PAKAN IKAN KEMPAR}

Pelatihan life skill pembuatan pakan ikan ini merupakan kegiatan pendamping program pengabdian ini. Meski demikian tidak mengurangi minat dan antusias warga komunitas nelayan "Sido Mulyo". Pelatihan Life skill dilakukan dalam beberapa tahap, yang meliputi tahap uji coba pembuatan pakan ikan berbentuk pelet, tahap uji kualitas pelet dan tahap pelatihan pembeuatan pakan ikan berbentuk pelet da komunitas nelayan.

1. Tahap Uji Coba Pembuatan Pakan Ikan berbentuk Pelet 
Tahap ini bertujuan untuk menetukan resep yang pas sehingga didapatkan pelet pakan ikan yang memenuhi kualitas. Pada kenyataannya uji coba tidak cukup dilakukan hanya satu kali saja tetapi dua kali sehingga mencapai tujuan yang diharapkan.

Uji coba pertama kali dilakukan tanggal 10 Mei 2016 di Laboratorium Kimia UIN Walisongo. Sebelumnya tim pengabdi menyiapkan alat dan bahan yang diperlukan. Pada awalnya semua bahan yang akan digunakan tidak diberi perlakuan apapun. Misalnya dedak yang berasal dari ricemill langsung dicampurkan dengan ampas tahu yang masih dalam keadaan basah (langsung dari pabrik tahu). Ikan kempar dalam keadaan setengah kering diblender sehingga didapatkan tepung ikan kempar yang agak basah. Semua bahan dicampur. Hasilnya berupa campuran yang mengandung kadar air yang tinggi sehingga pada uji coba pertama ini tiak ditambahkan air pada campuran. Campuran yang diperoleh selanjutnya digiling menggunakan alat penggiling daging manual dan didapatkan pelet pakan ikan. Hasil uji coba yang pertama ini memiliki kelemahan yaitu kadar air pelet ikan terlalu tinggi $(>12 \%)$. Selain itu ketika pelet ikan diujikan di air, maka pelet ikan langsung hancur atau stabilitasnya terhadap air rendah. Keesokan harinya pelet yang dihasilkan terlihat berjamur, disebabkan tingginya kadar air. Kadar air yang tinggi menyebabkan jamur dan mikroorganisme pembusuk lainnya sangat mudah berkembang. Evaluasi dari uji coba pertama ini adalah bahan utama seperti tahu dan tepung ikan harus dikurangi kadar airnya. Agar pelet memiliki stabilitas yang baik terhadap air maka perlu ditambahkan bahan perekat.

Uji coba yang kedua dilangsungkan pada tanggal 19 dan 20 Juli 2016 di Laboratorium Kimia UIN Walisongo. Namun sebelumnya, tim kami menyiapkan selauaruh bahan yang diperlukan dengan lebih baik dan teliti. Berdadasrkan evaluasi pada uji coba tahap pertama, kadar air dari pelet $>12 \%$ artinya masih tinggi. Untuk mengurangi kadar air pelet ikan, kami awali dengan mengurangi kadar air pada bahan baku dengan membuatnya menjadi tepung ampas tahu dan tepung ikan.Kemudian, kami gunakan kanji sebagai bahan perekat campuran dedak, tepung ampas tahu dan tepung ikan dengan tujuan untuk menjaga stabilitas pelet ikan terhadap air. Stabilitas yang baik membuat pakan tidak mudah hancur aat ditebarkan ke kolam ikan. Dengan demikian ikan yang ada dipermukaan kolam mendapatkan makanan dan ikan yang ada di dalam atau dasar kolam juga mendapatkan pakan. Pada uji coba kedua ini juga kami tambahkan vitamin minyak ikan (vitamin E) pada campuran sehingga dapat meningkatkan nilai gizi dari pakan ikan yang diperoleh. Baunya yang amis akan dapat menggungah selera makan ikan budidaya. 
Tepung ampas tahu dibuat dengan cara yang relatif sederhana. Ampas tahu yang didapat dari pabrik tahu diperas. Hasil perasaanya dikeringkan selama 3 hari dibawah terik sinar matahari. Tepung ampas tahu kering disimpan di dalam plastik.

Tepung ikan dibuat dari ikan kempar basah yang diperoleh dari nelayan. Ikan setelah dicuci kemudian dikukus hingga matang dengan tujuan untuk mengurangi kadar air dan kadar lemak pada ikan kempar. Selanjutnya, ikan dihancurkan dengan penggiling daging. Ikan yang sudah halus dikeringkan dibawah sinar matahari selama 3-4 hari. Hasilnya berupa tepung ikan kering dan siap untuk disimpan. Tepung ikan kempar dan tepung ampas tahu kering ini dapat disimpan dalam jangka waktu yang relatif lama (1 bulan lebih). Secara fisik, hasil uji coba pada tahap kedua ini lebih baik daibandingkan hasil pertama.

2. Uji Kualitas Pelet Pakan Ikan Kempar

Uji kualitas pelet pakan ikan ini bertujuan untuk mengetahui apakah pelet pakan ikan yang dihasilkan sudah memenuhi standar atau belum. Standar yang dimaksud adalah Standar Nasional Indonesia (SNI) no 7308 tahun 2009 yang dikeluarkan oleh Badan Standarisasi Nasional Departemen Perindustrian dan Perdagangan. Adapu uji kualitas yang dapat dilakukan pada program ini adalah uji sifat kimia meliputi uji kadar protein, kadar air, kadar abu dan uji sift fisika meliputi uji stabilitas dalam air dan daya apung atau kecepatan tenggelam. Semua uji tersebut dilakukan di Laboratorium Kimia UIN Walisogo.

Uji dilakukan terhadap hasil uji coba tahap kedua.

Tabel 1

Hasil Uji di Laboratorium Kimia UIN Walisogo Semarang

\begin{tabular}{clc}
\hline No & \multicolumn{1}{c}{ Uji } & Hasil \\
\hline 1 & Protein $(\%)$ & 10 \\
\hline 2 & Abu $(\%)$ & 10 \\
\hline 3 & Air $(\%)$ & 12 \\
\hline 4 & Stabilitas dalam air (menit) & 10 \\
\hline 5 & Waktu Tenggelam (menit) & 2 \\
\hline
\end{tabular}

Berdasarkan uji laboratorium tersebut, terdapat hasil uji yang sudah memenuhi standar SNI 7308 yaitu kadar abu (SNI <12\%), kadar air (SNI $<12 \%$ ) dan waktu tenggelam dalam air (SNI 2-5 menit). Adapun hasil uji yang masih dibawah standar adalah protein (SNI 20-30\%) dan stabilitas dalam air (2- 
3jam). Peningkatan kadar protein dapat disiasati dengan menggunakan tepung ikan kempar yang berasal dari ikan kempar segar.

Dalam program ini digunakan ikan yang sudah dikeringkan lebih dahaulu. Selain itu jumlah atau komposisi tepung ikan kempar sebaiknya lebih banyak dibandingkan dedak. Adapun stabilitas dalam air pada pakan ikan dapat disiasati dengan mengatur kadar air pada pelet ikan. Kadar air yang terlalu rendah menyebabkan pelet cepat hancur sedangkan kadar air yang tinggi menyebabkan waktu tenggelam akan menjadi lebih singkat karena berat jenis menjadi bertambah besar.

\section{Pembuatan Pelet Pakan Ikan Kempar}

Kegiatan ini dilaksanakan pada Senin, 25 Juli 2016. Kegiatan berlangsung selama tiga setengah jam mulai pukul 19.30-23.00 WIB. Jumah peserta yang hadir 18 orang terdiri dari 14 laki-laki dan 4 perempuan. Pada saat pelatihan peserta dibekali dengan buku panduan Life skills pembuatan Pakan Ikan Berbentuk Pelet. Buku Panduan dapat dilihat pada Lampiran...

Pelatihan diawali dengan tahlil dan doa bersama yang dipimpin oleh $\mathrm{H}$. Mustopa, M.Ag, anggota tim pengabdi. Selanjutnya penjelasan teoritik pembuatan pelet pakan ikan selama kurang lebih 1 jam dilanjutkan dengan simulasi pembuatan pelet ikan kempar oleh tim pengabdi dan dilanjutkan praktik langsung oleh warga yang hadir yang berlangsung selama 2,5 jam. Penjelasan diberikan oleh Wirda Udaibah, M.Si dan dimoderatori oleh H. Nur Khoiri, M.Ag.

Oleh pemateri dijelaskan bahwa daerah Tambak Mulyo memiliki potensi ikan yang melimpah yang dapat dimanfaatkan lebih lanjut dan tidak hanya dijual kepada tengkulak saja. Hal ini akan dapat menambah nilai jual dari ikan tersebut. Salah satu cara yang dapat dilakukan adalah dengan memanfaatka ikan kempar yang jumlahnya melimpah menjadi pakan ikan kering berbentuk pelel.

Sebenranya limbah ikan segar dapat langsung digunakan sebagai pakan ikan, tetapi ketersediaanya menjadi tidak tentu. Sesekali ada dan jumlahnya banyak namun kadang tidak ada atau jumlahnya sedikit. Untuk itu supaya ketersediaan pakan selalu mencukupi maka dibuat pakan ikan kering.

Pakan Ikan kering yang dibeli masyarakat biasanya harganya relatif mahal Rp 30.000, 00/kg. Jika lahan budi daya semakin luas maka akan semakin banyak modal dihabiskan hanya untuk pakan kering saja. Berdasarkan kajian, 60-80\% modal dalam budidaya ikan (ikan payau atau tawar) dihabiskan untuk pakan ikan kering. Mahalnya pakan ikan kering dapat disiasati dengan memproduksi pakan ikan sendiri dengan memanfaatkan limbah yang ada disekitar. Limbah yang dimaksud seperti limbah ikan kempar (ikan kempar yang jumlahnya melipah tapi 
tidak dimanfaatkan), dedak/bekatul yang merupakan limbah dari penggilingan padi, ampas tahu yang merupakan limbah dari pabrik tahu. Karena memanfaatkan limbah, harga bahan baku pembuatan pakan ikan menjadi relatif lebih rendah.

Pelatihan berlangsung lancar dan peserta cukup antusias dengan pelatihan tersebut. Hal ini dapat dilihat dari beberapa pertanyaan yang diajukan peserta dan antusias warga saat praktik. Pertanyaan yang mucul saat diskusi antara lain dari Bapak Nur Hadi yaitu bagaimana takaran dedak, ampas tahu dan tepung ikan dalam pembuatan pakan ikan komposisi bahan.

Untuk pertanyaan tersebut tanggapan yang dapat diberikan adalah, pada dasarnya komposisi atau takaran bahan baku pelet sesuai dengan keinginan si pembuat. Maksudnya jika ingin kadar protein yang tinggi dan pertumbuhan ikan cepat maka tepung ikandibaut lebih banyak dari yang lain. Jika menginginkan kadar karbohidrat yang tinggi maka dedak diperbanyak. Namun paling tidak komposisi dari smua bahan adalah 1: 1: 1 untuk dedak, tepung ikan dan tepung ampas tahu. Apabila tepung ikan terlalu banyak maka modal akan menjadi lebih besar dibanding yang tepung ikan sedikit.

Pertanyaan selanjutnya adalah dari Ibu - ibu ketika praktik berapa volume air yang ditambahkan dan sampai kapan pengadukan berlangsung. Volume air tidak ada takaran pasti, intinya hingga semua bahan tercampur rata dan wujud campuran seperti ketika debu (tanah) terkena gerimis/air hujan.tidak terlalu basah dan tidak terlalu kering. Dengan praktik langsung akan lebih paham tentang hal ini. Pengadukan terutama setelah ditambah kanji adalah sampai semua bahan seperti butiran pasir, tidak ngempel.

\section{HASIL PENYELENGGARAAN PENGUATAN KETERAMPILAN BACA TULIS AL-QUR'AN (BTA)}

Pendataan warga penyandang buta baca tulis al-Qur'an (BTA) pada komunitas nelayan "Sido Mulyo" di desa Tanjung Mas kecamatan Semarang Utara Kota Semarang, dilaksanakan pada Mei s/d Juni 2016. Dalam observasi tersebut di bantu oleh pimpinan komunitas nelayan, tokoh agama maupun tokoh masyarakat. Hasil pendataan calon warga ngaji komunitas nelayan "Sido Mulyo" di desa Tanjung Mas kecamatan Semarang Utara Kota Semarang, dapat dipaparkan pada tabel 2.

Selanjutnya dalam Proses pembelajaran Baca Tulis Al-Qur'an (BTA) pada kelompok nelayan "Sido Mulyo" di Tanjung Mas Kecamatan Semarang Utara Kota Semarang berjumlah 23 warga ngaji yang terdiri dari 15 laki-laki dan 8 perempuan. Adapun perinciannya dapat dilihat pada tabel 3. 
Tabel 2

Daftar Pendataan Calon Warga Ngaji

Kelompok Nelayan Sido Mulyo di Desa Tanjung Mas Kecamatan Semarang Utara Kota Semarang

\begin{tabular}{ccc}
\hline No & Jenis Kelamin & Jumlah Calon WN \\
\hline 1. & Laki-Laki & $18 \mathrm{WN}$ \\
\hline 2. & Peremuan & $8 \mathrm{WN}$ \\
\hline & \multirow{2}{*}{ Jumlah } & $26 \mathrm{WN}$ \\
& & \\
\hline
\end{tabular}

\section{Keterangan:}

WN (Target): Jumlah warga ngaji minimal yang harus diperoleh.

Calon WN : Jumlah warga ngaji hasil pendataan (observasi).

Tabel 3

Daftar Warga Belajar Yang Mengikuti Proses Pembelajaran

Baca Tulis Al-Qur'an (BTA) pada Kelompok Nelayan Sido Mulyo di Desa

Tanjung Mas Kecamatan Semarang Utara Kota Semarang

\begin{tabular}{lccc}
\hline No & Jenis Kelamin & Jumlah & Jumlah WN (Hasil) \\
\hline 1 & Calon WN & $18 \mathrm{WN}$ & $15 \mathrm{WN}$ \\
\hline 2 & Perempuan & $8 \mathrm{WN}$ & $8 \mathrm{WN}$ \\
\hline & Jumlah & $\mathbf{2 6} \mathbf{W N}$ & $23 \mathbf{W N}$
\end{tabular}
Keterangan:
WN (Target)
: Jumlah warga ngaji minimal yang harus di peroleh.
Calon WN
: Jumlah warga ngaji hasil pendataan (observasi).
WN (Hasil)
: Jumlah warga ngaji yang ikut proses pembelajaran
BTA

Evaluasi atau penilaian dalam program pelaksanaan Penuntasan Buta Baca Tulis Al Qur'an merupakan satu kesatuan integral yang terintegrasi dengan proses pembelajaran yang dilakukan sebelumnya, selama dan setelah pembelajaran. Penilaian pada hakikatnya merupakan upaya pengamatan, 
pelaksanaan dan tindak lanjut. Penilaian merupakan serangkaian kegiatan yang bertujuan untuk memperoleh, menganalisis dan menafsirkan data tentang input, proses dan hasil dari setiap warga belajar yang dilakukan secara sistematis dan berkesinambungan sehingga menjadi informasi yang bermakna dalam mengambil keputusan.

Kegiatan penilaian menitikberatkan pada keaktifan warga belajar dan penerapan hasil pembelajaran. Pada setiap tahapan penilaian dilakukan secara partisipatif dan menghindari suasana-suasana pengujian atau tes terhadap waga belajar yang mengesankan suasana formalitas dan situasi yang menegangkan. Dengan kata lain, pelaksanaan tes berlangsung dalam suasana santai dan tidak terkesan bahwa warga belajar sedang dites.

Kemampuan setiap warga belajar pada awal masuk kelompok belajar tidaklah sama, setiap warga belajar memiliki kemampuan awal yang berbedabeda. Dari warga yang belum mengenal huruf hijaiyyah sama sekali sampai dengan yang sudah mengetahui huruf hijaiyyah dalam standar tertentu. Oleh karena itu, tutor mengelompokkan warga belajar yang berstatus Buta Baca Tulis al-Qur'an Murni menjadi sub kelompok dan memberikan pembelajaran sesuai dengan kemampuan yang dimiliki warga belajar, serta memberikan pembelajaran dengan penuh kesabaran. Sehingga tingkat pencapaian hasil pembelajaran dapat segera mencapai sasaran.

Adapun warga belajar yang sudah mengenal aksara dengan standar tertentu, tutor memberikan pembelajaran kehijaiyyahan dan ketajwidan. Selain itu tutor juga memberikan bimbingan serta arahan sehingga warga belajar dapat membaca, menulis dan menghafal huruf dan surat-surat al-Qur'an secara baik dan benar. Adapun evaluasi dilakukan baik sebelum, selama, maupun sesudah pembelajaran.

Sebelum pembelajaran dilakukan Pre-Test yang berguna untuk:

a. Mengetahui tingkat kehijaiyyahan dan ketajwidan warga belajar.

b. Pengelompokan warga.

c. Perumusan tujuan belajar.

d. Penentuan materi dan strategi/metode pembelajaran.

e. Pembuatan kesepakatan belajar.

Dan selama proses pembelajaran, evaluasi digunakan untuk :

a. Mengetahui kemajuan warga belajar.

b. Mengetahui efektifitas strategi / metode pembelajran.

c. Menilai efektifitas bahan ajar yang digunakan.

d. Perubahan / perbaikan rencana pembelajaran untuk peningkatan materi pembelajran. 
e. Bahan pelaporan.

Serta akhir pembelajaran, evaluasi digunakan untuk :

a. Mengetahui pencapaian hasil belajar (tingkat kompetensi warga belajar).

b. Mengetahui efektifitas strategi / metode pembelajaran.

c. Menilai efektifitas bahan ajar yang digunakan.

d. Perencanaan progran lanjutan.

e. Bahan pelaporan.

f. Sertifikasi (SYAHADAH).

Adapun jumlah warga ngaji yang dinyatakan lulus evaluasi adalah 23 warga ngaji yang terdiri dari 15 Laki-Laki dan 8 Perempuan, yang dapat dipaparkan sebagai berikut:

Tabel 4

Daftar Warga Belajar Yang Lulus Evaluasi Hasil Belajar

Baca Tulis Al-Qur'an (BTA) Kelompok Nelayan Sido Mulyo di Desa Tanjung Mas Kecamatan Semarang Utara Kota Semarang

\begin{tabular}{llccc}
\hline No & Kelompok & $\begin{array}{c}\text { Jumlah } \\
\text { Calon WN }\end{array}$ & $\begin{array}{c}\text { Jumlah } \\
\text { WN } \\
\text { (Hasil) }\end{array}$ & Jumlah WN (Lulus) \\
\hline 1 & Laki-Laki & $18 \mathrm{WN}$ & $15 \mathrm{WN}$ & $15 \mathrm{WN}$ \\
\hline 2 & Perempuan & $8 \mathrm{WN}$ & $8 \mathrm{WN}$ & $8 \mathrm{WN}$ \\
\hline
\end{tabular}

Keterangan:

WN (Target) : Jumlah warga ngaji minimal yang harus diperoleh.

Calon WN : Jumlah warga ngaji hasil pendataan (observasi).

WN (Hasil) : Jumlah warga ngaji yang ikut proses pembelajaran.

WNL (Lulus) : Jumlah warga ngaji yang lulus belajar baca tulis al-Qur'an.

Berangkat dari perbedaan kemampuan keaksaraan warga ngaji, maka dalam melakukan pembelajaran diterapkan strategi yang berbeda antara satu dengan yang lain. Perbedaan tersebut seperti ada yang belum mengenal huruf arab sama sekali dengan yang sudah mengetahui huruf arab dalam standar tertentu. Oleh karena itu, tutor mengelompokkan warga ngaji yang belum mengenal huruf arab sama sekali menjadi sub kelompok dan memberikan pembelajaran yang sesuai dengan kemampuan yang dimiliki warga ngaji, serta 
memberikan perhatian penuh kesabaran, sehingga tingkat pencapaian hasil pembelajaran dapat segera mencapai sasaran.

Kemampuan setiap warga belajar memiliki tingkat dan hasil yang berbeda-beda. Adapun tingkatan pembelajaran warga belajar dapat dilihat dari status pendidikan Al-Qur'an mereka, sedangkan hasil pembelajaran warga belajar dapat ditinjau dari tiga unsur kompetensi, antara lain:

1. Drop Out kelas 1 Madrasah (DO 1)

a) Kitabah (menulis)

b) Qiro'ah (membaca)

c)Muhafadloh (menghafal)

2. Drop Out kelas 2 Madrasah (DO 2)

a) Kitabah (menulis)

b) Qiro'ah (membaca)

c) Muhafadloh (hafalan)

3. Drop Out kelas 3 Madrasah (DO 3)
a) Kitabah (menulis)
b) Qiro'ah (membaca)
c)Muhafadloh (hafalan)

4. Murni, yaitu masyarakat yang sama sekali belum pernah memiliki pengalaman pendidikan di Madrasah

a) Kitabah (menulis)

b) Qiro'ah (membaca)

c)Muhafadloh (hafalan)

Adapun warga ngaji yang sudah mengenal huruf arab dengan standar tertentu, tutor memberikan kesempurnaan pembelajaran baca tulis al-qur'an, selain itu tutor juga memberikan bimbingan dan arahan, sehingga warga ngaji dapat membaca dan menulis huruf arab, serta berhitung dan berkomunikasi secara terampil dengan baik dan benar, mampu melafaldkan ayat-ayat pendek dan dapat menghafal ayat-ayat pendek tersebut.

Dari hasil evaluasi yang kami lakukan, kami dapat menyimpulkan bahwa terdapat perkembangan yang signifikan yang dialami oleh warga ngaji. Perkembangan tersebut berbeda antara satu warga dengan yang lainnya. Jika dilihat prosentase tingkat pencapaian hasil akhir dan dibandingkan dengan target awal, proses pendidikan baca tulis al-Qur'an yang kami lakukan bisa dikategorikan baik dan berhasil, hal ini dikarenakan nilai antara target dengan hasil ahirnya dapat terpenuhi bahkan lebih dari $100 \%$, meskipun secara keseluruhan baru mencapai 96\% namun hal tersebut dapat disempurnakan 
dengan dampingan berlanjut. Adapun prosentase hasil pembelajaran warga ngaji yang berhasil di tuntaskan dapat di lihat dalam tabel berikut ini:

\section{Tabel 5}

Tingkat Pencapaian Hasil Pembelajaran

Kelompok Sido Mulyo di Desa Tanjung Mas Kecamatan Semarang Utara Kota Semarang

\begin{tabular}{cccccc}
\hline \multirow{2}{*}{ Kelompok } & Target & \multicolumn{3}{c}{ Hasil } & \multirow{2}{*}{ Prosentase } \\
\cline { 2 - 5 } & $\mathbf{W N}$ & $\mathbf{C W N}$ & $\mathbf{W N}$ & $\mathbf{W N L}$ & \\
\hline Laki-Laki & $16 \mathrm{WN}$ & $18 \mathrm{WN}$ & $15 \mathrm{WN}$ & $15 \mathrm{WN}$ & $94 \%$ \\
\hline Perempuan & $8 \mathrm{WN}$ & $8 \mathrm{WN}$ & $8 \mathrm{WN}$ & $8 \mathrm{WN}$ & $100 \%$ \\
\hline Jumlah & $24 \mathbf{W N}$ & $\mathbf{2 6}$ & $\mathbf{2 3} \mathbf{W N}$ & $\mathbf{2 3} \mathbf{W N L}$ & $\mathbf{9 6} \%$ \\
\hline
\end{tabular}

\section{Keterangan:}

WN (Target): Jumlah warga ngaji minimal yang harus di peroleh Tim.

Calon WN : Jumlah warga ngaji hasil pendataan (observasi) Tim.

WN (Hasil) : Jumlah warga ngaji yang ikut proses pembelajaran

WNL: Jumlah warga ngaji yang lulus belajar baca tulis al-Qur'an

Rangkaian program pengabdian berlangsung lancar dengan berbagai dukungan dari berbagai pihak, meskipun masih ditemui beberapa hambatan. Faktor pendukung dalam kegiatan ini antara lain:

1. Adanya kerjasama dari masing-masing tim pengabdian pada masyarakat.

2. Kerjasama dengan tokoh agama dan tokoh masyarakat dalam menumbuhkan motivasi dan minat Warga Masyarakat Buta baca tulis alqur'an serta menimbulkan rasa aman dan nyaman dalam melaksanakan kegiatan pembelajaran pendidikan Baca Tulis Al-Qur'an.

3. Masyarakat menyambut dengan baik dan ramah

4. Warga ngaji mempunyai semangat yang tinggi untuk belajar

5. Terjalinnya hubungan kekeluargaan antara tim pengabdian pada masyarakat dan aparat desa dengan Warga ngaji.

6. Dukungan dari tokoh agama dan tokoh masyarakat desa lokasi pengabdian.

7. Adanya sebagian warga yang membantu dalam mencari warga ngaji.

8. Adanya kesadaran pentingnya pendidikan dalam diri warga ngaji.

9. Adanya semangat dari warga ngaji dalam pembelajaran. 
10. Para peserta antusias dan interaktif dengan bertanya tentang proses pembuatan pelet pakan Ikan kempar. Hal ini sesuai dengan potensi yang ada pada daerah mereka berupa ikan kempar yang jumlahnya melimpah dan harga jual relatif murah.

Adapun faktor yang menghambat kegiatan ini antara lain:

1. Faktor lingkungan yaitu adanya banjir rob di wilayah Tambak Mulyo yang berlangsung cukup lama (Sepanjang bulan Juni). Hal ini menyebabkan kegiatan KPD tidak terjadwal sesuai waktu yang dijadwalkan. Untuk life skills faktor penghambat lainnya adalah kurangnya alat dan modal usaha. Alat yang digunakan dalam pencetakan pelet adalah alat yang dimodifikasi dari penggiling daging dan akan lebih baik juka dihubungkan dengan mesin diesel sebagai tenaga penggerak. Untuk merangkai alat tersebut harganya relatif mahal. Untuk mesin diesel kapsitas 12pk saja (kecil) harganya mencapai 12 juta rupiah. Komunitas Nelayan "Sido Mulyo" belum siap untuk menyediakan alat tersebut.

2. Kondisi warga yang kebanyakan kerja di waktu siang hari

3. Usia warga ngaji kebanyakan sudah di atas usia dewasa sehingga membutuhkan strategi dan metode tersendiri dalam pembelajaran.

4. Rendahnya daya ingat warga ngaji.

5. Rendahnya pengetahuan warga ngaji tentang pentingnya pendidikan baca tulis al-Qur'an.

6. Banyak warga yang didata tapi keluar karena berbagai faktor, ada yang karena malu, banyak kerjaan dan lain-lain.

7. Munculnya apatisme sebagian warga ngaji bahwa mereka telah terlambat untuk belajar.

8. Ada sebagian masyarakat yang malu atau tidak mau didata sebagai calon warga ngaji.

9. Ada sebagian masyarakat yang tidak aktif mengikuti program.

10. Kesulitan secara fisik karena adanya keterbatasan penglihatan, harus menggunakan alat bantu kacamata.

11. Beberapa warga ngaji masih malu untuk mengikuti proses pembelajaran.

12. Alokasi waktu yang diberikan dirasa terlalu singkat apalagi dengan target yang sangat besar.

13. Sarana dan prasarana pembelajaran yang kurang memadai.

14. Karena warga ngaji semuanya adalah orang dewasa bahkan beberapa sudah tua, maka hal ini menyebabkan daya fikir warga ngaji rendah. 
15. Munculnya apatisme warga ngaji bahwa mereka telah terlambat untuk belajar.

\section{KESIMPULAN}

Dalam melaksanakan Pengabdian pada Masyarakat "Penguatan Mutu Baca Tulis Al-Qur'an (BTA) melalui metode al-Masyburoh Berbasis Life Skill Pengolahan Limbah Ikan pada Komunitas Nelayan” di Desa Tanjung Mas Kecamatan Semarang Utara Kota Semarang, maka dapat diambil kesimpulan: Pertama, Program Pengabdian pada Masyarakat kali ini adalah terjun langsung ke masyarakat yang bersifat Non Fisik dan edukatif. Dalam rangka turut serta membantu Kementrian Agama dengan pola kegiatan Penuntasan Buta Baca Tulis AlQur'an (BTA). Dalam melakukan program ini diperlukan kerja yang cukup keras baik tenaga, pikiran, kesabaran, kedekatan dan sarana prasarana yang menunjang, di antaranya adalah program ketrampilan dan program desa yang up to date. Untuk mempermudah tercapainya cita-cita pemerintah dalam penuntasan Buta Baca Tulis Al-Qur'an di Jawa Tengah, khususnya di Kota Semarang.

Kedua, dalam menunjang tingkat perekonomian warga masyarakat di desa Tanjung Mas Kecamatan Semarang Utara Kota Semarang kami mencoba memberikan pendidikan keterampilan hidup (life skill) diantaranya adalah pengolahan pelet/pakan dari limbah ikan. Bekal yang diberikan tidak sebatas pada pelatihan saja tetapi juga membantu dalam pengurusan ijin produksi dan kelayakan pengolahan pelet tersebut, serta mencarikan peluang dalam pemasaran hasil olahan tersebut.

Ketiga, hasil utama pengabdian pada masyarakat 'Penguatan mutu Baca Tulis Al-Qur'an (BTA) Melalui Metode Al-Masyburob Berbasis Life Skill Pengolahan Limbah Ikan Pada Komunitas Nelayan” tahun 2016 antara lain:

a) Penuntasan warga masyarakat komunitas nelayan khususnya kelompok nelayan "Sido Mulyo" dari Buta Huruf Arab; dapat membaca, menulis, dan menghafal surat-surat pendek Al-Qur'an sebanyak 23 orang (94\% dari target maksimal 24 orang) warga ngaji.

b) Memberikan life skill pada warga ngaji; Pengolahan pelet dari limbah ikan, dll.

c) Berperan aktif dalam kegiatan kemasyarakatan dan pemerintahan desa. 


\section{DAFTAR PUSTAKA}

Adi, Isbandi Rukminto 2001. Pemberdayaan, Penngembangan Masyarakat dan Intervensi Komunitas (Pengantar Pada Pemikiran dan Pendekatan Praktis). Lembaga Penerbit Fakultas Ekonomi Universitas Indonesia

Afrianto, E dan Liviawaty. 2005. Pakan Ikan. Yogyakarta: Kanisius.

Alip, 2010. Mesin Pellet Ikan Terapung. Dalam http://mesinpeletikan.blogspot.com/. Diakses pada 15 Juni 2016. 09:17 WIB.

Al-Jamali, Muhammad Fadil. 1986. Filsafat Pendidikan dalam Al-Quran. Surabaya: Bina Ilmu

Amin Abdullah. 2004. Pendidikan Islam dan Tantangan Globalisasi. Yogyakarta: Presma.

Amirudin, J., 2015. Pengaruh Kadar Air terhadap Kualitas Fisik dan Kimiawi Pakan Gel untuk Ikan Koi Cyprinus Haematopterus, Program Studi Budidaya Perairan, Jurusan Perikanan Fakultas Ilmu Kelautan dan Perikanan Universitas Hasanuddin, Makasar

Dewi, Palupi. 2001. Skripsi: Uji Sifat Fisik Ransum Ikan Bentuk Pelet dengan Penyemprotan Air Panas dan Penmabahan Perekat Tepung Tapioka. Bogor: Fakultas Peternakan. Institut Pertanian Bogor.

Ditjen Pesisir dan Pulau-pulau Kecil Departemen Kelautan dan Perikanan R.I. 2003. Pedoman Umum Program PEM T.A. 2003

Dradjat, Zakiah. 1994. Pendidikan Islam dalam Keluarga dan Sekolah. cet. 1. Jakarta: Ruhama

Effendi, Supli. 2009. Teknologi Pengolahan dan Pengawetan Pangan. Jakarta: Alfabeta

Gunardi, dkk. 2004. Pengantar Pengembangan Masyarakat (Modul SEP-520). Jurusan Ilmu Sosial Ekonomi Fakultas Pertanian IPB dan Program Pasca Sarjana IPB 
Irfak, K. 2013. Skripsi: Desain Optimal Pengolahan Sludge Padat Biogas Sebagai Bahan Baku Pakan Ikan Lele di Magetan Jawa Timur. Malang: Fakultas Pertanian. Universitas Brawijaya.

Kharim, Muhamad. 2009. Pendidikan Kritis dan Informatif. Jogjakarta: Ar ruz.

Kordi, K. 2007. Meramu Pakan untuk Ikan Karnivora. Semarang: Aneka Ilmu.

Kurniawan, P.S. Membuat Sendiri Pakan Lele Alternatif. www.alamtani.com (diakses tanggal 15 mei 2016).

Kusnadi. 2000. Nelayan, Strategi Adaptasi dan Jaringan Sosial. Humaniora UtamaPress-Bandung

Langgulung, Hasan. Azas-azas Pendidikan Islam.

Muhadjir, Noeng. 2000. Ilmu Pendidikan Dan Perubahan Sosial. Yogyakarta: Rake Sarasin.

Muhadjir, Noeng. 1996. Pendidikan Islam untuk Masa Depan Kemanusiaan. Jakarta: Jurnal Ilmiah Pendidikan Islam Lektur.

Muliawan, Jasa Ungguh. 2008. Epistemologi Pendidikan. Yogyakarta: Gadjah Mada University Press.

Muzayin, Arifin. 1988. Pendidikan Islam Dalam Arus Dinamika Masyarakat. Jakarta: Golden Terayon.

Nata, Abuddin. 2011. Perspektif Islam Tentang Strategi Pembelajaran. Jakarta:Kencana Media Group

Nurfadhila, dkk. 2011. Fermentasi: Teknologi Sederbana Pengolahan Bahan Baku Lokal dalam Pembuatan Pakan Ikan. Bogor: Fakultas Perikanan. Institut Pertanian Bogor.

Pidarta, Made. 1997. Landasan Pendidikan Stimulus Ilmu Pendidikan Bercorak Indonesia. Cet. 1. Jakarta: Rineka Cipta, 
Pidarta, Made. 2007. Landasan Kependidikan. Jakarta: Asdi Mahasatya

Prasetya, 2002. Filsafat Pendidikan.Cet.2. Bandung: Pustaka Setia.

Purwanto, M. Ngalim. 1998. Ilmu Pendidikan Teoritis dan Praktis. Bandung: PT. Remaja Rosdakarya.

Rahman, Abdul. 2004. Skripsi: Suplementasi Ransum yang Mengandung Ikatan Ampas Tabu dan Ampas Bir dengan Zn dan Cu Terbadap Produksi Susu Sapi Perah. Bogor: Fakultas Peternakan. Institut Pertanian Bogor.

Rasyaf, M. 1994. Beternak Ayam Pedaging. Jakarta: Penebar Swadaya.

Rozy, Edo Jendra Esa. 2008. Skripsi: Pengaruh Penambahan Bentonit dan Air Panas pada Sifat Fisik Ransum Bentuk Pelet. Bogor: Fakultas Peternakan. Institut Pertanian Bogor.

Saputro, T, Cara membuat Tepung Ikan dengan Mudah. www.ilmuternak.com. (diakses tanggal 15 Mei 2016)

Satria, Arif. 2001. Dinamika Modernisasi Perikanan (Formasi Sosial dan Mobilitas Nelayan). Humaniora Utama Press-Bandung

Setyono, B. 2012. Pembuatan Pakan Buatan, Unit Pengelola Air Tawar. Malang: Kepanjen

SNI 7308. 2009. Pakan Buatan untuk Ikan Bandeng Budidaya Intensif. Jakarta Pusat: Perpustakaan BSN.

Sudiyono, H. M. 200. Ilmu Pendidikan Islam. Jakarta : PT. Rineka Cipta.

Susanto, Nugroho Juni. 2006. Skripsi: Optimalisasi Pemanfaatan Ikan Pepetek (Leiognathus sp.) dan Ubi Jalar Putih (Ipomoea batatas L.) untuk Subtitusi Parsial Tepung Terigu dalam Pembuatan Biskuit. Bogor: Fakultas Perikanan dan Ilmu Kelautan. Institut Pertanian Bogor.

Suwarno, Wiji. 2009. Dasar-Dasar Ilmu Pendidikan. Jogjakarta: Ar- Ruzz Media 
Tindjabate, Christian. 2002. Aspek Sosial Budaya dalam Perencanaan dan Pengelolahan Wilayah Pesisir dan Laut Secara Terpadu. Makalah dalam Pelatihan ICZM Kerjasama MCRMP Bappeda Provinsi Sulawesi Tengah dengan Pusat Penelitian Kelautan dan Pemberdayaan Masyarakat Pesisir-Universitas Taduloka

Tirtarahardja, Umar dan La sulo. 2005. Pengantar Pendidikan. Jakarta: Rineka Cipta

Tonny, Fredian dan Kolopaking, L.M, 2004. Sosiologi untuk Pengembangan Masyarakat Modul SEP-51B. Jurusan Ilmu-ilmu Sosial Ekonomi Fakultas Pertanian IPB dan Program Pasca Sarjana IPB

Uhbiyati, Nur. 1997. Imm Pendidikan Islam. Bandung: Perpustakaan Setia.

Wikantiasi, Apit. 2001. Skripsi: Uji Sifat Fisik Ikan Jenis Pelet Tenggelam dengan Proses Pengukusan dan Timgkat Penambahan Tepung Tapiokan sebagai Perekat. Bogor: Fakultas Peternakan. Institut Pertanian Bogor.

Yuslinawati. 2006. Skripsi: Isolasi dan Karakterisasi Sifat-sifat Fungsional Protein Ampas Tabu. Bogor: Fakultas Teknologi Pertanian. Institut Pertanian Bogor.

Zaenuri, dkk. 2014. Jurrnal Sumber Daya Alam dan Lingkungan: Kualitas Pakan Ikan Berbentuk. Pelet dari Limbah Pertanian. Malang: Fakultas Teknologi Pertanian. Universitas Brawijaya. 